\title{
Strategi Komunikasi Kementerian Pemberdayaan Perempuan Dan Perlindungan Anak (Kemenpppa) Dalam Menanggapi Kasus Sinetron Suara Hati Istri : Zahra
}

\author{
Hanny Novita ${ }^{1}$, Ahmad Junaidi ${ }^{2}$ \\ ${ }^{1}$ Fakultas Ilmu Komunikasi, Universitas Tarumanagara, Jakarta \\ Email:hannynovita23@gmail.com \\ ${ }^{2}$ Fakultas Ilmu Komunikasi, Universitas Tarumanagara, Jakarta* \\ Email:ahmadd@fikom.untar.ac.id
}

Masuk tanggal : 30-11-2021, revisi tanggal : dd-mm-yyyy, diterima untuk diterbitkan tanggal : dd-mm-yyyy

\begin{abstract}
With the development of technology, people's lives cannot be separated from the mass media. Television is one of them, television has a major influence on the development of society, especially in association. Soap operas that are liked by many people, one of which is the soap opera entitled "Suara Hati Wife: Zahra". This soap opera was reprimanded by the Indonesian Broadcasting Commission (KPI) because one of the players took the role of the third wife and was performed by an underage artist. According to the Ministry of Women's Empowerment and Child Protection, this soap opera has a large enough impact on the community so that early childhood stimulation emerges. The type of research method used by the researcher is a qualitative method using the case study method. The results of this study show that the Ministry of Women's Empowerment and Child Protection carries out various communication strategies for child marriage in the case of the soap opera Zahra's wife's conscience.
\end{abstract}

Keywords: Ministry of Women's Empowerment and Child Protection, communication strategy, child marriage, soap operas

\begin{abstract}
Abstrak
Dengan adanya perkembangan teknologi, kehidupan masyarakat tidak lepas dari media massa. Televisi salah satunya, Televisi memiliki pengaruh besar terhadap perkembangan masyarakat, terutama dalam pergaulan. Sinetron yang disukai oleh banyak orang salah satunya adalah sinetron berjudul "Suara Hati Istri : Zahra". Sinetron ini diberi teguran oleh pihak Komisi Penyiaran Indonesia (KPI) karena salah satu pemain yang mendapatkan peran sebagai istri ketiga dan dilakukan oleh artis yang berada di bawah umur. Menurut Kementrian Pemberdayaan Perempuan dan Perlindungan Anak, sinetron ini memberikan dampak yang cukup besar di kalangan masyarakat sehingga muncullah stimulasi usia dini. jenis metode penelitian yang digunakan oleh peneliti yaitu metode kualitatif dengan memakai metode studi kasus Hasil dari penelitian ini menunjukkan Kementerian Pemberdayaan Perempuan dan Perlindungan Anak melakukan berbagai macam strategi komunikasi terhadap perkawinan anak dalam kasus sinetron suara hati istri Zahra.
\end{abstract}

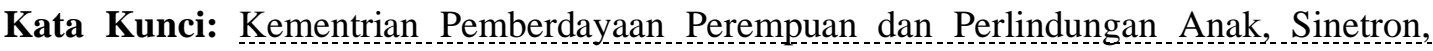
Perkawinan Anak, Strategi Komunikasi

\section{Pendahuluan}

Komunikasi berperan penting bagi masyarakat dikehidupan sehari-hari, fungsi komunikasi mulai yang bersifat persuasif, edukatif, dan infromatif. Bentuk kegiatannya akan selalu melakukan proses yang tidak dapat dihindari yaitu 
komunikasi. karena tanpa adanya komunikasi, tidak ada proses interaksi yang dilakukan oleh masyarakat.

Menurut Barelson \& Stainer dalam buku Human Behavior, didefinisikan komunukasi adalah: "Komunikasi adalah penyampaian informasi, gagasan, emosi, keterampiln dan lain sebagainya dengan menggunakan lambang-lambang atau katakata, gambar, bilangan grafik, dan lain-lain. Kegiatan atau proses penyampaiannya biasanya dinamakan komunikasi" (Ruslan, 2002).

Dengan berkembangnya ilmu dan teknologi, kehidupan masyarakat tidak terlepas dari media massa. Karena itu muncul berbagai sarana komunikasi untuk membantu penyebaran informasi secara menyeluruh. Media yang efektif dalam penyebaran informasi adalah media massa. Media yang dipakai untuk berkomunikasi disebut media massa.

Televisi adalah media massa yang populer dari dulu hingga sekarang. "Televisi memiliki kelebihan dalam penyampaian pesan-pesannya dibandingkan media massa lain, pesan yang disampaikan pada media televisi dalam gambar dan suara secara luas bersaman (sinkron) membuat televisi lebih menarik perhatian masyarakat." (J.B Wahyudi, 1986).

Di Indonesia, televisi adalah media yang berfungsi sebagai penyebaran informasi sekaligus media hiburan. Karena perkembangan teknologi media televisi menjadi sangat beragam. Program yang ditayangkan telvisi juga memiliki beragam keunggulan dan tujuan tertentu. Namun, sayangnya ada beberapa program televisi yang tidak memiliki nilai yang baik untuk keadaan sehari-hari. Seperti dalam sinetronsinetron remaja yang menggambarkan bahwa sekolah bukan hanya sebagai tempat untuk belajar, melainkan sebagai tempat untuk berpacaran, berkelahi dan sebagainya.

Saat ini televisi memiliki pengaruh untuk masyarakat luas, karena dengan adanya tayangan televisi tersebut mereka mulai mengikuti gaya hidup yang ada di televisi (Schement,2012). Dimasa sekarang, televisi banyak menayangkan acara reality show dan sinetron karena program tersebut banyak menarik minat masyarakat. Seiring berjalannya waktu, tayangan televisi dengan program acara sinetron semakin membawa dampak yang negatif ke masyarakat.(Wardhana, 2012).

Banyak sinetron yang disukai oleh banyak orang, salah satunya adalah sinetron Suara Hati Istri : Zahra yang ditayangkan di Indosiar. Sinetron ini telah diberi teguran oleh pihak Komisi Penyiaran Indonesia (KPI) karena salah satu pemain film mendapat peran sebagai istri ketiga dan dilakukan oleh artis yang masih berada dibawah umur. KPI meminta pihak stasiun televisi untuk mengevaluasi sinetron tersebut (Kompas.com).

Sinetron memiliki gejala yang menggambarkan perilaku yang membahayakan bagi remaja-remaja pada saat ini, karena remaja pada saat ini pada umumnya mulai memperlihatkan kebiasaan-kebiasaaan yang diberikan oleh sinetron. Usia remaja khususnya yang masih dibawah umur (12-17 tahun) rentan mengikuti perilaku dari sintron yang ditayangkan, terutama perilaku orang tua yang membahayakan anaknya yaitu pernikahan anak.

Menurut KemenPPPA, sinetron Suara Hati Istri : Zahra membawa dampak yang cukup besar dilakangan masyarakat, karena dengan adanya sinetron ini muncullah dorongan untuk pernikahan dini yang bertentangan dengan program Pemerintah (mediaindonesia.com).

Didalam Undang Undang tentang perkawinan dijelaskan bahwa ada usia minimum untuk menikah. 


\section{Metode Penelitian}

Peneliti memakai penelitian metode kualitatif. Penelitian yang dipakai untuk lebih memahami sesuatu yang dialami oleh subjek penelitian dalam bentuk kata dan bahasa disebut penelitian kualitatif. (Moleong, 2007).

Objek penelitian ini, peneliti melihat secara rinci aktivitas masyarakat yang ada di tempat tertentu.

Subyek penelitian adalah data yang diambil sesuai dengan kegiatan penelitian. Sumber data dalam penelitian ini adalah subyek dimana data di peroleh (Suharsimi Arikunto, 2002).

Dari penelitian ini, yang menjadi objek adalah strategi komunikasi yang dilakukan. Sedangkan subjeknya adalah Kementrian Pemberdayaan Perempuan dan Perlindungan Anak Indonesia (KemenPPPA).

Sugiyono (2010), mengatakan "teknik analisis data merupakan proses mencari data, menyusun secara sistematis data yang diperoleh dari hasil wawancara, catatan lapangan, dan dokumentasi, dengan cara mengategorikan data, menafsirkan ke dalam unit-unit, melakukan sintesis, menyusun ke dalam pola memilih mana yang penting dan yang akan dipelajari, dan membuat kesimpulan sehingga mudah dipahami oleh diri sendiri maupun orang lain".

Penelitian ini menggunakan metode studi kasus yang bermaksud mendeskripsikan suatu keadaan. Yin (2013) mengatakan "studi kasus merupakan suatu inkuiri empiris yang menyelidiki fenomena di dalam konteks kehidupan nyata, bilamana batas-batas antara fenomena dan konteks tak tampak dengan tegas dan dimana multisumber bukti di manfaatkan".

Peneliti menggunakan teknik pengolahan dan analisis data dan menetapkan key informant sesuai dengan topik yang diteliti yaitu Kementrian Pemberdayaan Perempuan dan Perlindungan Anak. Peneliti melakukan metode pengumpulan data (wawancara, studi kepustakaan, dan dokumentasi) serta melakukan pemilihan data dan dilampirkan sebagai data pendukung dalam penelitian ini sehingga peneliti mampu melakukan analisis dan menarik kesimpulan.

Dalam penelitian ini uji keabsahan datanya menggunakan uji triangulasi dimana pengujian kredibilitas sebagai pengecekan data dari berbagai sumber dengan berbagai waktu. (Sugiyono, 2007)

\section{Hasil Temuan dan Diskusi}

\section{Strategi Komunikasi Kementrian Pemberdayaan Perempuan dan Perlindungan Anak Indonesia (KemenPPPA) tentang sinetron Zahra yang mengacu pada perkawinan anak}

Menurut Middleton dalam Cangara (2013:61) "strategi komunikasi adalah kombinasi terbaik dari semua elemen komunikasi mulai dari komunikator, pesan, saluran (media), penerima sampai pada pengaruh (efek) yang dirancang untuk mencapai tujuan komunikasi yang optimal”.

Dari hasil wawancara dengan narasumber 1, Kementrian Pemberdayaan Perempuan dan Perlindungan Anak Indonesia (KemenPPPA) merupakan salah satu lembaga yang mengatasi permasalahan hak anak di Indonesia. Salah satu contoh kasus yang ditangani oleh lembaga ini adalah adanya laporan tentang pernikahan anak. perkawinan anak yang masih terjadi saat ini sangatlah disayangkan. Perkawinan anak 
yang terjadi cukup menjadi perhatian bagi pemerintah karena dampak yang ditimbulkan.

Untuk mencegah terjadinya perkawinan anak yang terjadi saat ini, KemenPPPA melakukan Gerakan Bersama Pencegahan Perkawinan Anak (Geber PPPA) dan juga melakukan kampanye persuasif yang berisikan edukasi-edukasi dan informatif tentang bahayanya pernikahan anak.

Untuk melaksanakan tugasnya, KemenPPPA membuka kanal pengaduan melalui berbagai sosial media, pengaduan ini akan langsung dikelola oleh staff yang tim yang ada di KemenPPPA.

Berdasarkan narasumber 1, dengan adanya Gerakan Bersama Pencegahan Perkawinan Anak (Geber PPPA) berhasil menurunkan persentase yang semula $11.21 \%$ menjadi $10.82 \%$ pada tahun 2019 .

\section{Kementrian Pemberdayaan Perempuan dan Perlindungan Anak Indonesia (KemenPPPA) dalam menyikapi kasus sinetron Suara Hati Istri : Zahra}

Menurut narasumber 1, sinetron Suara Hati Istri : Zahra sinetron ini kurang pantas untuk ditayangkan, karena dikhawatirkan akan memunculkan stimulasi pernikahan dini bagi para orang tua. Dengan adanya pemeran Zahra yang diperankan oleh anak dibawah umur sudah dinilai bahwa sinetron ini sudah melanggar UU yang mengatur tentang perkawinan anak. Saat ini sinetron Suara Hati Istri Zahra sudah diberhentikan dan sedang dilakukan evaluasi. Sinetron pada saat ini tidak hanya ditonton oleh orang dewasa saja, tetapi anak-anak dibawah umurpun sudah menonton sinetron yang ditayangkan di televisi. KemenPPPA berharap Komisi Penyiaran Indonesia lebih berhati-hati dalam melakukan penyaringan acara-acara tv yang akan ditayangkan karena peran dari Komisi Penyiaran Indonesia sendiri adalah mengawasi dan membina setiap acara tv yang ditayangkan di Indonesia. Dan narasumber juga mengatakan kasus perkawinan anak yang terjadi saat ini sangatlah disayangkan karena perkawinan anak yang terjadi akan memberikan dampak yang tidak baik bagi anak itu sendiri dan bagi negara Indonesia. KemenPPPA juga melakukan upaya untuk meminimalisir terjadinya pernikahan anak, salah satu upaya yang telah dilakukan adalah Gerakan Bersama Pencegahan Perkawinan Anak (Geber PPPA) dan melakukan kampanye untuk menolak pernikahan anak yang akan disebar di sosial media.

\section{Komisi Penyiaran Indonesia (KPI) dalam menyikapi Sinetron Suara Hati Istri : Zahra}

Gerbner mengatakan teori kultivasi pada efek televisi kumulatif sehingga membentuk realitas baru sesuai citra realitas televisi. Dengan kata lain, teori kultivasi memfokuskan bahwa dampak televisi yang sangat kuat terhadap perubahan pemahaman publik. (Miller, 2002).

Komisi Penyiaran Indonesia (KPI) sedang melakukan evaluasi terhadap sinetron Suara Hati Istri : Zahra yang ditayangkan di Indosiar, sinetron ini mendapatkan banyak kritik karena pemeran Zahra yang berperan sebagai istri ke-tiga yang diperankan oleh anak di bawah umur dan hal ini memunculkan kontroversi terhadap sinetron Suara Hati Istri : Zahra.

Peran dari Komisi Penyiaran Indonesia sangatlah penting dalam setiap penayangan acara tv di televisi. Sinetron merupakan gambaran yang diambil dari kehidupan seharihari dan dengan tayangnya sinetron ini di khawatirkan akan memunculkan stimulasi pernikahan dini dan hal ini ditentang oleh pemerintah karena melanggar pedoman penayangan televisi. Saat ini, sinetron Suara Hati Istri: Zahra sudah diberhentikan dan 
hal ini diharapkan dapat memperbaiki alur cerita serta pemeran yang ada disinetron tersebut.

\section{Organisasi Sahabat Anak dalam menyikapi Sinetron Suara Hati Istri : Zahra}

Pernikahan dini yang masih kerap terjadi saat ini sangat disayangkan karena dampak yang ditimbulkan cukup fatal. Organisasi Sahabat Anak mendukung penuh pemerintah yang mengeluarkan kebijakan tentang pertentangan pernikahan anak, karena pernikahan dini tidak hanya menimbulkan dampak negatif bagi diri anak saja, tetapi juga negara. Sahabat Anak berencana akan melakukan kampanye yang mengajak masyarakat untuk mendukung pertentangan terhadap pernikahan anak. Sosialisasi yang akan dilakukan berupa informasi dan edukasi kepada publik tentang dampak yang di sebabkan dari pernikahan dini. Organisasi Sahabat Anak juga tidak setuju dengan Sinetron Suara Hati Istri : Zahra, karena dengan adanya peran Zahra akan memunculkan stimulasi pernikahan dini dan orangtua akan mengganggap bahwa pernikahan anak menjadi hal yang biasa karena ditayangkan di televisi, dimana saat ini hampir semua khalayak menonton sinetron baik dari umur dewasa hingga dibawah umur. Maka dari itu Organisasi Sahabat Anak menentang adanya pernikahan anak untuk kebaikan dan kepentingan anak.

\section{Simpulan}

Kesimpulan dari skripsi dengan topik Strategi Komunikasi Kementrian Pemberdayaan Perempuan dan Perlindungan Anak Indonesia (KemenPPPA) adalah sebagai berikut :

Pernikahan anak yang masih kerap terjadi sampai saat ini harus dihentikan dengan berbagai upaya. Kasus sinetron Suara Hati Istri : Zahra saat ini menjadi perbincangan karena sinetron tersebut menjadi salah satu sinetron yang terjerumus kedalam pernikahan anak. "Sinetron Suara Hati Istri : Zahra mendapat teguran dari Komisi Penyiaran Indonesia karena telah melanggar Pedoman Perilaku Penyiaran dan Standar Program Siaran (P3\&SPS) KPI 2012.” Hal ini terjadi karena salah satu pemerannya mendapat peran sebagai istri ketiga dan diperankan oleh anak dibawah umur, dan ini dikhawatirkan akan memunculkan stimulasi pernikahan dini dikalangan masyarakat. KemenPPPA stasiun televisi yang menayangkan sinetron tersebut dan memberhentikan sementara tayangan sinetron tersebut. Pihak KemenPPPA berharap bahwa Komisi Penyiaran Indonesia (KPI) untuk lebih berhati-hati dalam melakukan penyeleksian acara tv yang akan ditayangkan di televisi. KemenPPPA juga melakukan upaya untuk mencegah terjadinya pernikahan anak, upaya yang telah dilakukan salah satunya adalah Gerakan Bersama Pencegahan Perkawinan Anak (Geber PPPA), gerakan ini merupakan inisiatif untuk menggiatkan upaya-upaya pencegahan pernikahan anak yang dilarang oleh pemerintah. Kementrian Pemberdayaan dan Perlindungan Anak juga melakukan upaya kampanye sebagai upaya pencegahan pernikahan anak yang terjadi saat ini. Kampanye yang dilakukan akan bersifat persuasif yang berisikan edukasi-edukasi dan informatif tentang bahayanya pernikahan anak.

\section{Ucapan Terima Kasih}

Puji syukur penulis panjatkan kepada Tuhan Yang Maha Esa karena atas kebaikan-Nya, peneliti menyelesaikan laporan penelitian dengan tepat waktu. Oleh 
karena itu, peneliti mengucapkan terima kasih kepada Bapak Ahmad Junaidi selaku dosen pembimbing skripsi penelitian, narasumber yang diwawancarai, serta yang membantu dalam pengerjaan laporan penelitian ini.

\section{Daftar Pustaka}

Azwar, Hreeloita Dharma Shanti, and Kintan Arumdhani. (2019). "Dampak Sinetron Indonesia Terhadap Perilaku Masyarakat (Analisis Kasus: Sinetron Anak Langit Di Sctv)." Journal of Digital Education, Communication, and Arts 2(2).

Beranda. (n.d.). Retrieved September 1, 2021, from https://kpi.go.id/index.php/id/

Cangara, Hafied, Perencanaan dan Strategi Komunikasi. Jakarta : PT Raja Grafindo Persada, 2014

Donata, Jessica, and Yugih Setyanto. 2020. "Strategi Komunikasi Kampanye Internal Greget Plastik Untuk Menumbuhkan Kesadaran Karyawan Dalam Mengurangi Penggunaan Plastik Sekali Pakai (Studi Pada PT Kalbe Farma Tbk).” Prologia 4(2).

Eleanora, Fransiska Novita, and Andang Sari. 2020. "Pernikahan Anak Usia Dini Ditinjau Dari Perspektif Perlindungan Anak." PROGRESIF: Jurnal Hukum 14(1).

Griffin, Emory A. (2004). A First Look At Communication Theory. New York: McGraw-Hill.

Junaidi, Junaidi. (2018). “Mengenal Teori Kultivasi Dalam Ilmu Komunikasi.” JURNAL SIMBOLIKA: Research and Learning in Communication Study 4(1).

KEMENTERIAN PEMBERDAYAAN PEREMPUAN DAN PERLINDUNGAN ANAK. (n.d.). Retrieved September 1, 2021, from https://www.kemenpppa.go.id/

Labib,M. (2002). Potret Sinetron Indonesia Antara Realitas Virtual dan Realitas Sosial.

Mulyana, Deddy. (2007). Ilmu Komunikasi Suatu Pengantar. Bandung: PT Remaja Rosdakarya.

Sugiyono, Metode Peneltian Kuantitatif, Kualitatif dan R\&D. Bandung : Alfabeta, 2015

Sahabat Anak - Ayo Penuhi Hak Anak Indonesia. (n.d.). Retrieved September 1, 2021, from https://sahabatanak.org/

Zuldafrial dan Lahir, M. (2012). Penelitian Kualitatif. Surakarta: Yuma Pustaka 